\title{
Effect of native Trichoderma viride and Pseudomonas fluorescens on the development of Cuscuta campestris on chickpea, Cicer arietinum
}

\author{
C. Kannan*, B. Kumar, P. Aditi ${ }^{1}$ and Y. Gharde \\ Directorate of Weed Science Research, Maharajpur Jabalpur- 482004 (M.P), INDIA \\ ${ }^{1}$ Department of Biological SciencesRani Durgavati University, Jabalpur- 482001 (M.P), INDIA \\ *Corresponding author E-mail: agrikannan@gmail.com
}

Received: September 13, 2014; Revised received: November 22, 2014; Accepted: December 18, 2014

\begin{abstract}
Cuscuta campestris Yuncker is a serious parasite on several leguminous crops including chickpea in India. Chickpea is an important pulse crop in India and severe incidence of Cuscuta may result in yield loss of about $85.7 \%$. Management of Cuscuta is very difficult because of their intricate relationship with the host, wide host range and lack of resistant genes in the host. Thus induced systemic resistance (ISR) by plant growth promoting microbes (microbial elicitors) may be an effective alternative method for the management of Cuscuta. In the current study, to induce systemic resistance, native isolates of Trichoderma viride Pers. and Pseudomonas fluorescens Flügge were used as seed treatments and foliar spray on chickpea and then infested with $C$. campestris. Salicylic acid and thiobenzamidazole (synthetic elicitors) were used as standard inducing agents for comparison. Results indicated that fresh seeds of $C$. campestris germinated rapidly even without scarification and that the germination was not influenced by the proximity of the seeds to the host. Seed treatment followed by foliar sprays with the bioagents and synthetic elicitors induced at 20 and 40 days after sowing (DAS) induced increased production of defense enzymes in chickpea (Cicer arietinum L.) and thus delayed the development (1.8-5 days) and flowering (2.4-4.2 days) of $C$. campestris. Treatment with both the elicitors also resulted in the enhanced activities of scavengers of enzymes related reactive oxygen species (ROS). Thus the above work would help in the integration of the application of bioagents for effective management of Cuscuta in chickpea.
\end{abstract}

Keywords: Chickpea, Cuscuta campestris, Defense enzymes, ISR, Pseudomonas fluorescens, Trichoderma viride

\section{INTRODUCTION}

Cuscuta spp. (commonly called as Dodder) are rootless, achlorophyllous, heterotrophic, obligate angiosperms twining on dicotyledonous crops. They belong to the family Cuscutaceae (earlier known as Convolvulaceae), containing about 170 different species distributed throughout the world (Holm et al., 1997). Cuscuta are broadly nonspecific, attacks a wide range of plant species including many cultivated plants and dicotyledonous weeds, but rarely the monocotyledonous plants (Wright et al., 2011). Cuscuta enjoys a very intimate relationship with the host plants throughout its life cycle, except for a very short, post germination independent period of about 810 days, in which even a two way transfer of genes between host and the parasite has been reported (Mower et al., 2004).

Among the 12 different species of Cuscuta reported to occur in India, $C$. campestris and $C$. reflexa are most common and cause significant economic losses on crops like niger, lucerne, berseem and chickpea (Gaur, 1999). Incidence of Cuscuta spp. is reported mainly in the states of Andhra Pradesh, Chhattisgarh, Gujarat, Odisha, West Bengal and Madhya Pradesh on oilseed crops like niger, linseed, pulses viz., blackgram, greengram, lentil, chickpea (prominently in rice-fallows) and fodder crops including lucerne, berseem (Mishra, 2009). Chickpea is an important pulse crop, cultivated in about 8.56 million ha with an annual production of 7.35 million tones and India is the largest producer, accounting for nearly $64 \%$ of the global production (Gaur et al., 2010). Vyas and Joshi (1975) first reported the incidence of Cuscuta sp on chickpea in the state of Uttar Pradesh, in India. Mishra (2009) reported that $C$. campestris is the dominant species attacking chickpea in India. Yield loss of about $85.7 \%$ has been reported in chickpea as a result of Cuscuta infestation (Moorthy et al., 2003) and 54.7 to $98.7 \%$ by $1-10$ C. campestris twines $/ \mathrm{m}^{2}$ (Mishra, 2009).

The choice of chemicals for control of Cuscuta is very limited. Pre-plant incorporation and post emergence application of imazethapyr at $75 \mathrm{~g} /$ ha produced better control of the Cuscuta on various crops (Mishra et al., 2007). Inherent genetic resistance in the host against Cuscuta is not very common (Lanini and Kogan, 2005) and crop rotation is not a feasible technique often because of its wide host range. Thus induced systemic 
resistance (ISR) by microbes is thought of as an integrated strategy in the management of Cuscuta. Plant growth promoting microbes induce resistance in plants by activation of host anti-stress genes to produce more defense proteins and phytoalexins against plant pathogens ( Van loon et al. 1998; Kannan and Karthik, 2009; Sriram et al., 2009), alter the composition of host root exudates and their volatile signaling molecules (Harsh et al., 2006), thereby interfering with the recognition of the host by the parasite. Cuscuta resembles the plant pathogenic fungi in the use of haustoria as the main invading organ to infect and establish in the host (Meyer, 2006) and thus would fit well in the scheme of management by ISR. Keeping this in view, the present investigation was conducted to study the effect of native Trichoderma viride and Pseudomonas fluorescens on the development of Cuscuta campestris on chickpea (Cicer arietinum). This study would help in the integrated management of Cuscuta by means of application of microbes at appropriate stages of cultivation. Further since the awareness about the ill effects of more usage of pesticides is increasing, this safe and natural method of management using friendly microbes would be of significant importance in the overall strategy for the management of this dreaded weed.

\section{MATERIALS AND METHODS}

Location: Experiments were conducted in controlled conditions in the containment facility at the Directorate of Weed Science Research (DWSR), Jabalpur (23 ${ }^{0} 13^{\prime} 59.00$ 'N, 79 $58^{\circ} 02.25$ 'E, elevation 390.45m) during 2009 to 2012. C. campestris seeds were collected from the farmer's fields in Mandla district of

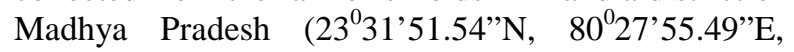
elevation $456.60 \mathrm{~m})$.

Antagonistic microbes: Fungal and bacterial bioagents were isolated from native soils of chickpea using appropriate selective media viz., Trichoderma selective medium (Elad et al., 1981) for T. viride and King's B for $P$. fluorescens. To prevent attenuation the bioagents were periodically inoculated in the pots with chickpea infested by $C$. campestris and again reisolated.

Effect of antagonists and synthetic elicitors on Cuscuta C. campestris on chickpea: Plastic tubs of size $30 \mathrm{~cm}^{3}$ were filled with pot mixture containing sterilized soil, sand and decomposed (Farm Yard Manure) FYM (1:1:1). Locally popular variety of chickpea, JG-16 was sown and seedlings were thinned to maintain 2 healthy seedlings per pot. Seeds of $C$. campestris was sown by thoroughly mixing about 20 seeds with the top soil of the pot and with a rose can, watered gently using tap water $(\mathrm{EC}=2 \mathrm{ds} / \mathrm{m}, \mathrm{pH}=$ 7.1).

Antagonists were multiplied in their respective broths, 6 days ( $P$. fluorescens) and 10 days ( $T$. viride) by incubating at $30{ }^{\circ} \mathrm{C}$ in a shaking incubator, after which the broth solution along with the microbial mat was collected, homogenized in a blender and applied as foliar spray or used for seed treatment. Synthetic elicitors $0.5 \mathrm{M} v i z$., salicylic acid and thiobenzamidazole (Bion $50 \%$ obtained from M/s Syngenta India Ltd.) were similarly used for comparison. Chickpea treated with distilled water was maintained as control.

Antagonists- chickpea-Cuscuta interactions: To study Induced Systemic Resistance (ISR) in chickpea, the potted plants were treated with the bioagents and infested with Cuscuta. The treatments with five replications per treatment are given as follows:

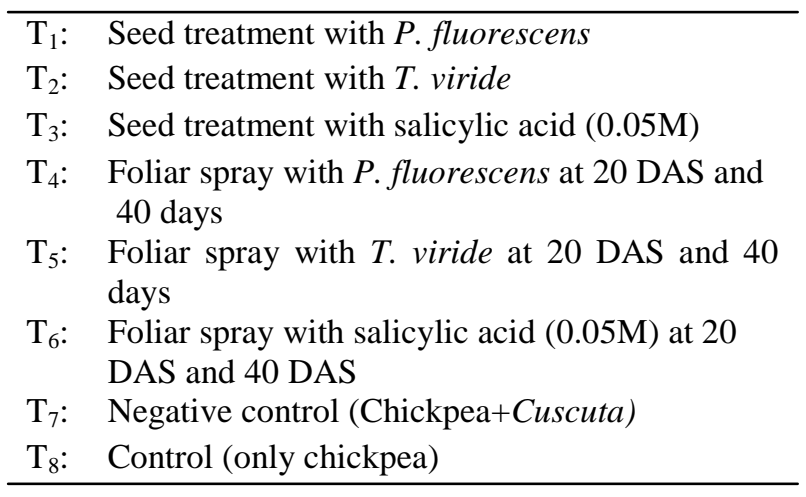

Activity of five key defense enzymes viz., Chitinase $(\mathrm{CH})$, Catalase (CT), Poly Phenol Oxidase (PPO), Peroxidase (PO) and Phenylalanine Ammonia Lyase (PAL) were estimated from the stem tissues of young plants collected from the above treatments periodically viz., immediately after the spraying ( 0 day), and further upto 50 days at an interval of 10 days from application, when the enzyme activity became static or declines. Colorimetric assay of enzyme $\mathrm{CH}$ was carried out according to Boller and Mauch (1988). PAL activity was estimated as described by Dickerson et al. (1984). The enzyme PO was analysed as given by Hammerschmidt et al. (1982), CT according to Aebi (1983) and PPO according to Meyer et al. (2000). To study the activity of the antioxidant enzymes like superoxide dismutase (SOD), Glutathione Reductase (GR) and Glutathione Peroxidase (GPX) both in chickpea and $C$. campestris, the samples were drawn from the above experiments and analyzed. The SOD activity was estimated using xanthine-xanthine oxidase system as suggested by Beyer and Fridovich (1987). The enzyme GPX was assayed as per the method suggested by Inoue et al. (1999).

Statistical analysis: All the experiments were conducted in Randomized Block Design (RBD) for two consecutive years and since there were no significant interactions between observations, the data were combined over the years and subjected to analysis of variance (ANOVA). Regression analysis was used where appropriate: Otherwise means were separated using least significant difference (LSD) at $5 \%$ level of significance. Before the analysis, 
normality of data and the equality of variances were checked using Kolmogrov-Smirnov test and some variables were transformed using suitable transformation. ANOVA was performed on data using general linear models procedure using PROCANOVA procedure with the SAS 9.2 statistical software (SAS Institute Inc., USA). Significant differences between different treatments were observed using Tukey's Honest Significant Difference. Linear model was best fitted to the flowering in Cuscuta at different distance from host plant chickpea. The model is given as $\mathrm{Y}=\mathrm{a}+\mathrm{bx}$, where, $a$ and $b$ are the regression coefficients of the model and $\mathrm{y}$ and $\mathrm{x}$ represents the flowering in Cuscuta and distance of Cuscuta from the chickpea, respectively.

\section{RESULTS AND DISCUSSION}

Germination, host search and development of $\boldsymbol{C}$. campestris: From the above study, it was observed that C. campestris germinated within a period of 3-4 days after sowing without acid scarification, when the fresh seeds were used. Germination of $C$. campestris was not influenced by the distance of its seed to the host seedling (Table 1) and there was no significant difference in the percentage germination of $C$. campestris when sown at different distances from the host plant. However treatment of chickpea with the bioagents or the synthetic elicitors influenced the germination of the $C$. campestris seeds and also affects the number of days taken by $C$. campestris to establish in the host and initiate flowering (Table 2, Fig. 1). Bion, when applied as seed treatments caused maximum delay in establishment of $C$. campestris by 16.4 days $(30.50 \%$ over control) when sown at $12 \mathrm{~cm}$ away from the host, followed by salicylic acid 10.6 days $(28.3 \%$ over control) when sown at $6 \mathrm{~cm}$ away. Among the bioagents, $P$. fluorescens was able to delay the process of establishment by 10.42 days $(26.92 \%$ over control). However, when compared for the days taken to first flowering by $C$. campestris, which indicates the development and physiological maturity of the parasite, $P$. fluorescens was found to cause maximum delay of 25.20 days $(29.36 \%$ over control)

Table 1. Effect of seed treatment and folia spray of bioagents and synthetic elicitors on germination and host search of Cuscuta in chickpea.

\begin{tabular}{|c|c|c|c|c|c|c|c|c|}
\hline \multirow[t]{2}{*}{ Treatments } & \multicolumn{4}{|c|}{ Cuscuta infecting chickpea (DAS) } & \multicolumn{4}{|c|}{ Flowering in Cuscuta (DAS) } \\
\hline & $3 \mathrm{cms}$ & $6 \mathrm{cms}$ & $9 \mathrm{cms}$ & $12 \mathrm{cms}$ & $3 \mathrm{cms}$ & $6 \mathrm{cms}$ & $9 \mathrm{cms}$ & $12 \mathrm{cms}$ \\
\hline $\begin{array}{l}\text { Seed treatment followed } \\
\text { by foliar spray with } \\
T . \text { viride at } 20 \text { DAS and } \\
45 \text { days }\end{array}$ & $6.80 \mathrm{ab}$ & $9.00 \mathrm{bc}$ & $12.40 \mathrm{a}$ & $13.20 \mathrm{c}$ & $20.40 \mathrm{c}$ & $22.00 \mathrm{ab}$ & $26.60 \mathrm{c}$ & $29.40 \mathrm{~b}$ \\
\hline $\begin{array}{l}\text { Seed treatment followed } \\
\text { by foliar spray with } P \text {. } \\
\text { fluorescens at } 20 \text { and } \\
45 \text { DAS }\end{array}$ & $7.00 \mathrm{ab}$ & $10.40 \mathrm{ab}$ & $13.40 \mathrm{a}$ & $14.40 \mathrm{bc}$ & $25.20 \mathrm{a}$ & $23.00 \mathrm{a}$ & $28.80 \mathrm{a}$ & $31.00 \mathrm{ab}$ \\
\hline $\begin{array}{l}\text { Foliar spray with salicylic } \\
\text { acid }(0.05 \mathrm{M}) \text { at } 20 \\
\text { DAS and } 45 \text { DAS }\end{array}$ & $7.40 \mathrm{a}$ & $10.60 \mathrm{a}$ & $12.80 \mathrm{a}$ & $14.80 \mathrm{~b}$ & $23.20 \mathrm{~b}$ & $22.80 \mathrm{a}$ & $27.20 \mathrm{bc}$ & $29.80 \mathrm{ab}$ \\
\hline $\begin{array}{l}\text { Foliar spray with Bion } \\
(0.05 \mathrm{M}) \text { at } 20 \mathrm{DAS} \text { and } \\
45 \text { DAS }\end{array}$ & $8.00 \mathrm{a}$ & $10.80 \mathrm{a}$ & $13.40 \mathrm{a}$ & $16.40 \mathrm{a}$ & $24.00 \mathrm{ab}$ & $23.40 \mathrm{a}$ & $28.40 \mathrm{ab}$ & $31.20 \mathrm{a}$ \\
\hline $\begin{array}{l}\text { Chickpea+C.campestris } \\
\text { (control) }\end{array}$ & $5.80 \mathrm{~b}$ & $7.60 \mathrm{c}$ & $9.80 \mathrm{~b}$ & $11.40 \mathrm{~d}$ & $17.80 \mathrm{~d}$ & $20.40 \mathrm{~b}$ & $22.20 \mathrm{~d}$ & $27.00 \mathrm{c}$ \\
\hline LSD@0.05 & 1.20 & 1.40 & 1.38 & 1.40 & 1.39 & 1.85 & 1.33 & 1.78 \\
\hline \multirow[t]{2}{*}{ Treatments } & & & & \multicolumn{4}{|c|}{ Coefficient estimates } & $\mathbf{R 2}$ \\
\hline & & & & \multicolumn{2}{|c|}{$\mathbf{a}(\mathbf{S E})$} & \multicolumn{2}{|c|}{$\mathbf{b}(\mathrm{SE})$} & \\
\hline \multicolumn{4}{|c|}{$\begin{array}{l}\text { Seed treatment followed by foliar spray with } T \text {. viride at } 20 \\
\text { DAS and } 45 \text { days }\end{array}$} & \multicolumn{2}{|c|}{$16.70(1.06)$} & \multicolumn{2}{|c|}{$1.05(0.13)$} & 0.97 \\
\hline \multicolumn{4}{|c|}{$\begin{array}{l}\text { Seed treatment followed by foliar spray with } P \text {. fluorescen } \\
\text { at } 20 \text { and } 45 \text { DAS }\end{array}$} & \multicolumn{2}{|c|}{$20.10(0.54)$} & \multicolumn{2}{|c|}{$0.92(0.07)$} & 0.99 \\
\hline \multicolumn{4}{|c|}{$\begin{array}{l}\text { Foliar spray with salicylic acid }(0.05 \mathrm{M}) \text { at } 20 \mathrm{DAS} \text { and } 45 \\
\text { DAS }\end{array}$} & \multicolumn{2}{|c|}{$19.5(1.36)$} & \multicolumn{2}{|c|}{$0.83(0.17)$} & 0.92 \\
\hline \multicolumn{4}{|c|}{ Foliar spray with Bion $(0.05 \mathrm{M})$ at 20 DAS and 45 DAS } & \multicolumn{2}{|c|}{$19.80(1.41)$} & \multicolumn{2}{|c|}{$0.93(0.172)$} & 0.94 \\
\hline \multicolumn{4}{|c|}{ Chickpea + C.campestris (control) } & \multicolumn{2}{|c|}{$14.5(1.20)$} & \multicolumn{2}{|c|}{$0.98(0.15)$} & 0.96 \\
\hline
\end{tabular}




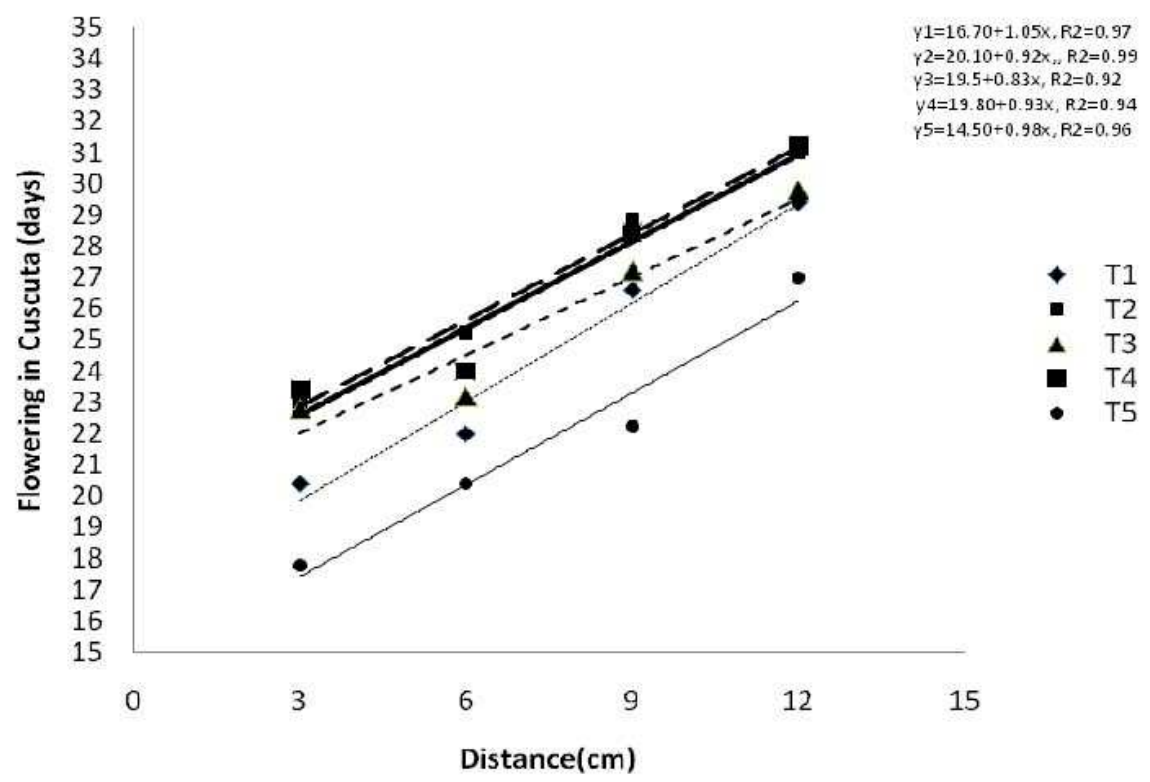

Fig. 1. Changes to first flowering in Cuscuta in response to different treatments and distance of sowing from the chickpea.

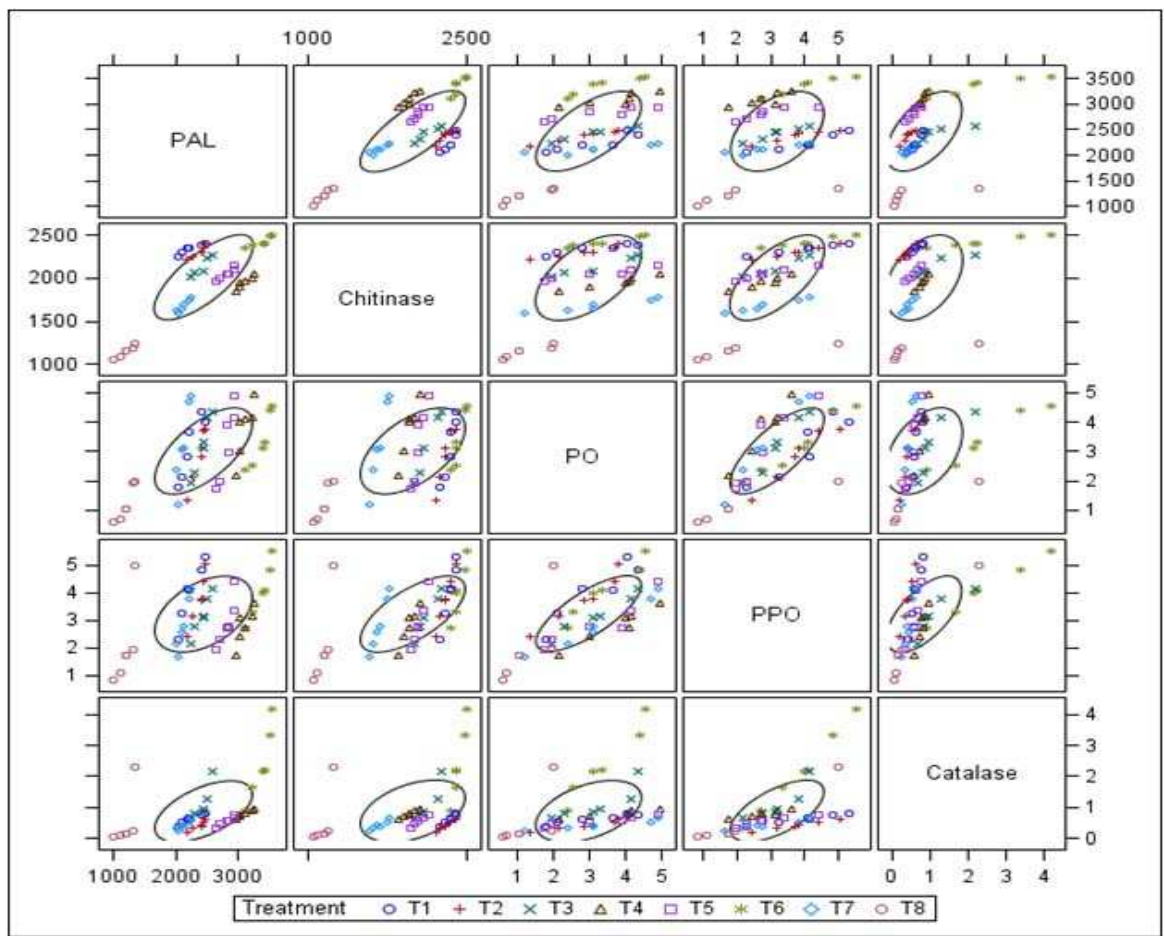

Fig. 2. Scatter plot matrix showing the relationship among different defense enzymes.

when sown at $3 \mathrm{~cm}$ away from the host. This was followed by the treatment with bion (24 days and $25.83 \%$ over control).

Linear model was best fitted to the flowering in Cuscuta at different distance from host plant chickpea. Results shows that initially, maximum delay in flowering occurs in treatment $T_{2}$ (at 20.10 days) followed by treatment $\mathrm{T}_{4}$ (19.80 days) with slope 0.92 and 0.93 respectively. As the distance of the Cuscuta from the host plant increases, delays in flowering in Cuscuta also increases linearly.

Understanding the process of their parasitization and development would lead to develop efficient strategies for their management (Westwood et al., 2012). Contrast to the earlier reports about physical and physiological dormancy of $C$. campestris and about a high percentage of newly matured seeds of C. campestris not imbibing water to germinate readily (Hutchison and Ashton, 1980) and the need for acid scarification (Jayasuriya et al., 2008), our studies have proved that fresh seeds, before drying in the plants germinates immediately without any need for scarification. This indicates that when sprinkler irrigation is given just before the harvest of the crop, 


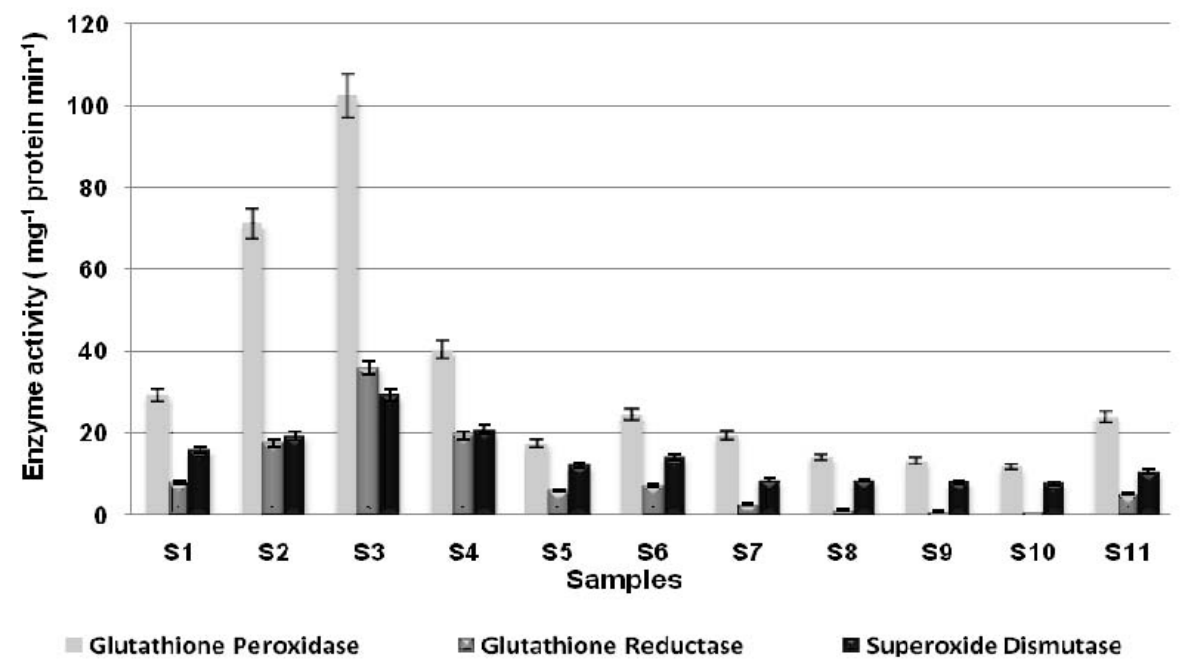

Fig. 3. Antioxidant enzyme activity in Chickpea and Cuscuta upon treatments with the bioagents and elicitors. Sample details$S_{1}:$ T. viride treated hickpea leaves; $S_{2}:$ P. fluorescence treated chickpea leaves; $S_{3}:$ 1ppm thiobendazole (Bion @50\% a.i.) treated chickpea leaves; $S_{4}$ : salicylic acid treated chickpea leaves; $S_{5}$ : Cuscuta infected chickpea leavs (Negative control); $S_{6}$ : Control (only chickpea leaves); $S_{7}:$ Only Cuscuta; $S_{8}:$ Cuscuta from T. viride treated chickpea plant; $S_{9}:$ Cuscuta from P. fluorescence treated chickpea plant; $S_{10}:$ Cuscuta from thiobendazole (1ppm Bion @ 50\% a.i.) treated chickpea plant; $S_{11}$ : Cuscuta from salicylic acid treated chickpea plant.

the matured seeds will be germinated and killed during subsequent harvest of the crop. Further irrigation prior to sowing the main crop, to optimum wetness would also result in the suicidal germination of the seeds of C. campestris. Further manual cleaning of the twines before they mature would result in the depletion of the parasitic weed seed bank in the soil.

Upon germination, green to yellow fine threads of $C$. campestris grew randomly for a day or and on reaching chickpea, the twines coils around the aerial parts, mainly the stem and leaves, produce haustoria to penetrate the host tissue and vascular system to draw the nutrients and water. Delayed flowering as an effect of bioagents and synthetic elicitor seed treatment could be due to the release of volatiles by the host to deter/ suppress the development of $C$. campestris. It is well established that $T$. viride and $P$. fluorescens application results in the overall development of systemic resistance in the host plants (ISR) (Van Loon et al., 1998).

Systemic resistance induced by antagonists in chickpea: Observation on the effect of the treatments of elicitors on $C$. campestris and chickpea indicated that seed treatment followed by foliar sprays at 20 and 40 DAS was found to have positive effect on the growth and health of the plants.

Estimation of defense enzymes at an interval of 10 days for 50 days indicated the initial increase, reaching a peak and the decline of enzymes activity in the plants (Table 3). This trend shows that the induction is purely temporary and the induction potential of the microbes and the elicitors decreases after a certain period of time (Kannan and Jose, 2009). Repeated application of the bioagents or the elicitors could maintain an enhanced activity of the enzymes which is evident from the fact that the seeds treated plants, followed by foliar spray of the elicitors (treatments $\mathrm{T}_{4}$ to $\mathrm{T}_{6}$ ) had overall more activity of the enzyme when compared with the plants with only seed treatment $\left(\mathrm{T}_{1}\right.$ to $\left.\mathrm{T}_{3}\right)$. Further the bioagents vary in their ability to induce different enzymes viz., $P$. fluorescens was very effective in inducing all the enzymes except $\mathrm{CH}$, while $T$. viride was found to induce more of $\mathrm{CH}$. However salicylic acid was most effective in inducing the enzymes than the microbes. These enzymes are key components of local and induced systemic resistance (Jankiewicz and Kołtonowicz, 2012). Though initially salicylic acid was better than microbes in inducing the defense enzymes, under natural conditions over a longer period of time the antagonistic microbes would build up their populations and induce the plants to produce more of the enzymes, which will not be the case with salicylic acid. Though BTH, a functional analogue of SA, has been reported as a successful resistance activator of plants (Oostendorp et al., 2001) in the current study it was found to suppress the initial growth of chickpea even at a very minimal dose.

The scatter plot matrix (Fig. 2) shows the relationship among five enzymes taken two at a time. Matrices reveal information like clusters and any outlier treatment among many treatments present in the data. In this plot, adjacent plots share common axis. It shows the eclipses which cover the maximum data points in it for different treatments. Those treatment values falling outside the eclipse shows significant difference with other treatment values. It also shows that in most of the comparisons, $\mathrm{T}_{6}$ outperforms all the treatments and $\mathrm{T}_{8}$ (control) have outliers and does not 
perform well.

Time $v s$ treatment interactions were studied for different enzymes and treatments using proc GLM procedure in SAS to know the significance of treatments on each point of time. Results indicated that the enzyme PAL had the highest activity in treatment $\mathrm{T}_{6}$ and the activity differed significantly for other treatments also. However, with respect to the enzyme PO, the treatments $T_{4}$ to $T_{7}$ showed significant variations at different points of time, but never showed a constant trend. Again the treatment $\mathrm{T}_{6}$ was found to be the best one for the enzymes $\mathrm{CH}$ and $\mathrm{CT}$ during the entire period of observation. All the enzymes except PPO showed significant interaction between treatment and time. PPO did show some significant changes between treatments at the early period of observations, but at later stages, the differences were non-significant. The activities of the antioxidant enzymes were estimated both in chickpea and $C$. campestris to analyze the effect of the treatments with the elicitors. It was observed GPX, GR and SOD were found to be maximum induced (102.36, 36.02 and 29.39 units $\mathrm{mg}^{-1}$ protein $\min ^{-1}$, respectively) by the application of bion as compared to control (Fig. 3). It was also observed that the antioxidant enzymes were more active in $C$. campestris (24.08, 5.36 and 10.79 units $\mathrm{mg}^{-1}$ protein $\min ^{-1}$, respectively) upon application of salicylic acid and the activation was significantly high when compared to treatment with the elicitors. In the case of GPX, P. fluorescens induced more activity of the enzyme (71.18 units $\mathrm{mg}^{-1}$ protein $\mathrm{min}^{-1}$ ) followed by salicylic acid (40.35 units $\mathrm{mg}^{-1}$ protein $\mathrm{min}^{-1}$ ), while these two treatments were at par in the case of GR and SOD. The biochemical activation and accumulation of defense enzymes, mainly the reactive oxygen scavengers, help in recovery of plants from the damage caused by the invasion of the parasite (Scandalios, 2005; Nyochembeng et al., 2007).

\section{Conclusion}

The above study showed that the fresh seeds of $C$. campestris germinate rapidly in a period of 5 to 6 days. This observation would help in suggesting that irrigation immediately before or after harvest of the crop, would induce the germination of Cuscuta seeds in soil and after germination, in the absence of the host would die, akin to the suicidal germination strategy followed for Orobanche and Striga with the use of germination stimulants. Application of $T$. viride and $P$. fluorescens elicited systemic resistance in chickpea, resulting in the increased production of defense enzymes, have better growth and suppresses growth of $C$. campestris. These microbes have already been established for their effective role in suppression of soil borne plant diseases and nematodes in chickpea. Thus the current study helps in emphasizing the application of these two microbes for better production of chickpea. Thus the overall results obtained in the current study gives a positive trend for the management of this dreaded weed in chickpea using the bioagents, which can be easily integrated with the existing management practices at minimal cost.

\section{REFERENCES}

Aebi, H. (1983). Catalase. In: Bergmeies H (ed) Methods of enzyme analysis. Chemie Wenhein, Verlag, pp 273-277.

Beyer, W.F. and Fridovich, I. (1987). Assaying for superoxide dismutase activity: some large consequences of minor changes in conditions. Annals of Biochemistry, 161: 559 -566 .

Boller, T. and Mauch, F. (1988). Colorimetric assay for chitinase. Methods in Enzymology, 161: 430 - 435.

Dickerson, D.P., Pascholati, S.F., Hangerman, A.E., Butler, L.G. and Nicholson, R.L. (1984). Phenylalanine ammonia-lyase and hydroxyl cinnanmate: CoA ligase in maize mesocotyls inoculated with Helminthosporium maydis or Helminthosporium carconum. Physiology and Molecular Plant Pathology, 25: 111-123.

Elad, Y., Chet, I. and Henis, Y. (1981). A selective medium for improving quantitative isolation of Trichoderma spp. from soil. Phytoparasitica, 9: 59-67.

Gaur, R.D. (1999). Flora of the District Garhwal. North West Himalaya, Transmedia, Srinagar Garhwal. pp: 443 $-444$.

Gaur, P.M., Tripathi, S., Gowda, C.L.L., Ranga Rao, G.V., Sharma, H.C., Pandey, S. and Sharma, M. (2010). Chickpea Seed Production Manual. Patancheru 502 324, Andhra Pradesh, India: International Crops Research Institute for the Semi-Arid Tropics. pp 28.

Hammerschmidt, R., Nockles, E.M. and Kuc, J. (1982). Association of enhanced peroxidase activity with induced systemic resistance of cucumber to Colletotrichum lagenarium. Physiology and Molecular Plant Pathology, 20: 73-82.

Harsh, P., Bais, Tiffany L., Weir, Laura G., Perry, Simon Gilroy and Jorge M., Vivanco. (2006). The Role of Root Exudates in Rhizosphere Interactions with Plants and Other Organisms. Annual Review of Plant Biology, 57: 233-66.

Holm, L., Doll, J., Holm, E., Panch, J. and Herberger, J. (1997). World Weeds: Natural Histories and Distribution. John Wiley \& Sons, New York. pp 1129.

Hutchison, J.M. and Ashton, F.M. (1980). Germination of field dodder (Cuscuta campestris). Weed Science, 28: 330-333.

Inoue, Y., Matsuda, T., Sugiyama, K., Izawa, S. and Kimura, A. (1999). Genetic analysis of glutathione peroxidase in oxidative stress response of Saccharomyces cerevisiae. Journal of Biological Chemistry, 274: 27002-27009.

Jankiewicz, U. and Kołtonowicz, M. (2012). The involvement of Pseudomonas bacteria in induced systemic resistance in plants. Applied Biochemistry and Microbiology, 48: 244-249.

Jayasuriya, K.M.G.G., Baskin, J.M. and Baskin, C.C. (2008). Cycling of sensitivity to physical dormancy- break in seeds of Ipomoea lacunose (Convolvulaceae) and ecological significance. Annals of botany, 101: 341-352.

Kannan, C. and Jose, C.T. (2009). Activation of defense enzymes in arecanut (Areca catechu L.) seedlings upon inoculation with biocontrol agents. Journal of Plantation Crops, 37 (2): 134-137.

Kannan, C. and Karthik, M. (2009). Systemic induction of 
defense enzymes by rhizosphere microbes in cocoa seedlings. Journal of Biological Control, 23(4): 427431.

Lanini, W.T. and Kogan, M. (2005). Biology and management of Cuscuta in crops. Ciencia e investigación agrarian, 32: $165-179$.

Meyer, A.M. (2006). Pathogenesis by fungi and by the parasitic plants: Similarities and differences. Phytoparasitica, 34: 3-16.

Meyer, U.M., Spotts, R.A. and Dewey, F.M. (2000). Detection and quantification of Botrytis cinera by ELISA in pear stems cold storage. Plant Disease, 84: 1099-1103.

Mishra, J.S., Moorthy, B.T.S., Bhan, M. and Yaduraju, N.T. (2007). Relative tolerance of rainy season crops to field dodder (Cuscuta campestris) and its management in niger (Guizotia abyssinica). Crop Protection, 26: 625629.

Mishra, J.S. (2009). Biology and Management of Cuscuta species. Indian J Weed Sci., 41: 1-11.

Moorthy, B.T.S., Mishra, J.S. and Dubey, R.P. (2003). Certain investigations on parasitic weed Cuscuta in field crops. Indian Journal of Weed Science, 35: 214216.

Mower, J.P., Stefanovic, S., Young, G.J. and Palmer, J.D. (2004). Gene transfer from parasitic Cuscuta to host plants. Nature, 432:165-166.

Nyochembeng, L.M., Beyl, C.A. and Pacumbaba, R.P. (2007). Peroxidase activity, isozymes pattern and electrolyte leakage in roots of Cocoyum infected with Pythium myaiotylum. Journal of Phytopathology, 155:
454-461.

Oostendorp, M., Kunz, W., Dietrich, B. and Staub, T. (2001). Induced disease resistance in plants by chemicals. European Journal of Plant Pathology, 107: 19-28.

Scandalios, J.G. (2005). Oxidative stress: molecular perception and transduction of signals triggering antioxidant gene defenses. Brazilian Journal of Medical and Biological Research, 38(7): 995-1014.

Sriram, S., Manasa, S.B. and Savitha, M.J. (2009). Potential use of elicitors from Trichoderma in induced systemic resistance for the management of Phytophthora capsici in red pepper. Journal of Biological Control, 23(4): 449 -456 .

Van Loon, L.C., Bakker, P.A.H.M. and Pieterse, C.M.J. (1998). Systemic resistance induced by rhizosphere bacteria. Annual Review of Phytopathology, 36: 453483.

Vyas, S.C. and Joshi, L.K. (1975). A new record of parasitic dodder on chickpea (Cicer arietinum L.). Current Science, 44: 701-702.

Westwood, J.H., dePamphilis, C.D., Das, M., Ferna'ndezAparicio, M., Honaas, L.A., Timko, M.P., Wafula, E.K., Wickett, N.J. and Yoder, J.I. (2012). The Parasitic Plant Genome Project: New Tools for Understanding the Biology of Orobanche and Striga. Weed Science, 60: 295-306.

Wright, M.A.R., Welsh, M. and Costea, M. (2011). Diversity and evolution of the gynoecium in Cuscuta (Convolvulaceae) in relation to their reproductive biology: two styles are better than one. Plant System and Environment, 296: 51-76. 